\title{
Estrogenic Evaluation and Organochlorine Identification in Blubber of North Sea Harbour Porpoise (Phocoena phocoena) Stranded on the North Sea Coast
}

\author{
Pedro Henrique Imazaki, ${ }^{1}$ François Brose, ${ }^{1}$ Thierry Jauniaux, ${ }^{2}$ Krishna Das, ${ }^{3}$ \\ Marc Muller, ${ }^{4}$ and Marie-Louise Scippo ${ }^{1}$ \\ ${ }^{1}$ Laboratory of Food Analysis, Department of Food Science, FARAH-Veterinary Public Health, University of Liège, Bâtiment B43b, \\ Quartier Vallée 2, Avenue de Cureghem 10, 4000 Liège, Belgium \\ ${ }^{2}$ Department of Morphology and Pathology, FARAH-Veterinary Public Health, University of Liège, Bâtiment B43, Quartier Vallée 2, \\ Avenue de Cureghem 6, 4000 Liège, Belgium \\ ${ }^{3}$ Laboratory for Oceanology, MARE Center, University of Liège, Bâtiment B6c, Quartier Agora, Allée du Six Aô̂t 11, \\ 4000 Liège, Belgium \\ ${ }^{4}$ Organogenesis and Regeneration, GIGA-R, University of Liège, Bâtiment B34, Quartier Hôpital, Avenue de l'Hôpital 1, \\ 4000 Liège, Belgium
}

Correspondence should be addressed to Marie-Louise Scippo; mlscippo@ulg.ac.be

Received 16 January 2015; Revised 24 March 2015; Accepted 7 April 2015

Academic Editor: Stelvio M. Bandiera

Copyright (C) 2015 Pedro Henrique Imazaki et al. This is an open access article distributed under the Creative Commons Attribution License, which permits unrestricted use, distribution, and reproduction in any medium, provided the original work is properly cited.

\begin{abstract}
Thirteen individual organochlorine compounds at 3 concentrations ( 80,400 , and $2000 \mathrm{ng} / \mathrm{mL}$ culture medium), as well as mixtures, were assayed for the estrogen receptor (ER) activation or inhibition, using a luciferase reporter gene assay (RGA). None of the PCB 138,153 , or 180 or their mixture induced a response in the RGA. $o, p^{\prime}$-DDT was the most potent xenoestrogen from the DDT group, inducing a response already at $80 \mathrm{ng} / \mathrm{mL}$. From the $\mathrm{HCH}$ and $\mathrm{HCB}$ group, only $\beta-\mathrm{HCH}$ (at 400 and $2000 \mathrm{ng} / \mathrm{mL}$ ) and $\delta$-HCH (at $2000 \mathrm{ng} / \mathrm{mL}$ ) displayed estrogenic activities. These 13 organochlorines were determined by GC-MS in 12 samples of North Sea harbor porpoise blubber. The PCBs were the main contaminants. Within each group, PCB $153\left(6.0 \times 10^{2} \sim 4.2 \times 10^{4} \mu \mathrm{g} / \mathrm{kg}\right), p, p^{\prime}-$ $\operatorname{DDE}\left(5.1 \times 10^{2} \sim 8.6 \times 10^{3} \mu \mathrm{g} / \mathrm{kg}\right)$, and HCB $\left(7.6 \times 10^{1} \sim 1.5 \times 10^{3} \mu \mathrm{g} / \mathrm{kg}\right)$ were the compounds found in highest concentrations. The hormonal activity of the porpoise blubber samples was also assayed in RGA, where two samples showed estrogenic activity, seven samples showed antiestrogenic activity, and one sample showed both estrogenic and antiestrogenic activity. Our results suggest that the 13 POPs measured by GC-MS in the samples cannot explain alone the estrogenicity of the extracts.
\end{abstract}

\section{Introduction}

The harbour porpoise (Phocoena phocoena) is the most common cetacean species in the North Sea [1], and there is a growing concern about the adverse effects of persistent environmental contaminants on this and other marine mammal species [2]. Since 1998, the southern region of the North Sea has been characterised by an increased number of stranded marine mammals, in particular the harbour porpoise. However, a temporary increase in the porpoise population in the southern North Sea may have been responsible [3, 4]. Since marine mammals are at the top of the aquatic food chain and have rather long lifespans, they are an important tool to check the long-term effects concerning marine environment pollution and can be studied as global pollution indicators as well [5].

Not all POPs released into the environment have the same bioaccumulation pattern in different species [6]. In this study, we investigated three nondioxin-like polychlorinated biphenyls (NDL-PCBs), which do not share the dioxin's toxic mechanism, and organochlorine pesticides (OCPs) such as dichlorodiphenyltrichloroethane (DDT) and its metabolites and hexachlorocyclohexane $(\mathrm{HCH})$ and its isomers. In marine mammals, POPs enter the body almost exclusively 
through the diet and since they are lipophilic compounds, they tend to accumulate in the lipid-rich blubber [7]. Moreover, because of the very low enzyme activities in marine mammals as compared to terrestrial animals, cetaceans have a low capacity to metabolise some persistent organic pollutants (POPs), and retain much higher concentrations of these chemicals in their fat $[8,9]$. For example, out of the NDLPCBs, congener 153 is hardly metabolised by the cytochrome P450 (CYP) enzymes, which makes this molecule extremely persistent [10]. In addition, the ability to metabolize PCB congeners is related to the levels of different families of CYP enzymes, which differ between cetaceans and other species [11]. DDT is metabolised by reductive dechlorination catalyzed by the microsomal CYP system. The principal metabolites generated are dichlorodiphenyldichloroethane (DDD) and dichlorodiphenyldichloroethylene (DDE), the latter being the most persistent and stable [12, 13]. Among $\mathrm{HCH}$ isomers, $\beta$-HCH seems to be more resistant to microbial degradation and thus more persistent in the environment than the other isomers [14]. While concentrations of OCPs (DDTs, HCB, and HCHs) in harbour porpoises stranded on the Belgian North Sea coast are low, relatively high concentrations of PCB are present [15].

Public concern about environmental contamination by POPs increased recently because of many evidences showing that some of these compounds are xenoestrogens and interact with the endocrine system, resulting in numerous biological effects that may affect the health of humans and animals $[7,16-20]$, as demonstrated in recent studies involving polar bears (Ursus maritimus) [21, 22]. It has been reported that PCBs are associated with reproductive, estrogenic and antiandrogenic, effects [23]. DDT and its metabolites bind the estrogen receptor [24], disrupting the endocrine and reproductive systems. Furthermore, $\mathrm{HCH}$ may also affect the reproductive system, possibly through endocrine-mediated mechanisms [25]. In the case of harbour porpoises, several studies have provided consistent support for the hypothesis of a PCB exposure induced immunosuppression contributing to infectious disease mortality [26, 27]. Furthermore, contaminants such as PCBs, DDT, and DDE may interfere with harbour porpoise thyroid functions leading to severe interfollicular fibrosis [28].

Currently, the United States Environmental Protection Agency (US-EPA) estimates that there are more than 87000 potential endocrine disrupters in the world. Nevertheless, developing methods to detect so many chemicals would take a massive financial mobilization. In this way, research on screening methods using short term bioassays to assess the risk of exposure to endocrine disrupting chemicals is needed $[29,30]$.

In this context, the aim of this study was to measure the hormonal activity of North Sea harbour porpoise blubber samples and to identify the compounds that contribute to the hormonal activity of these samples. In order to associate hormonal activities to xenoestrogen contamination levels, the samples were analysed both by cell-based assays (reporter gene assays) and chemical analysis (mass spectrometry coupled to gas chromatography [GC-MS]). GC-MS combines high separation power with good identification capabilities, while reporter gene assays allow the measurement of the hormonal potency of samples [31, 32], as they are based on the activation of the nuclear estrogen hormone receptor [33]. In this study, we decided to focus on the evaluation of the (anti-) estrogenic effect of xenoestrogens, as it is associated with disruption of the endocrine and reproductive systems. Studies combining biological and chemical analysis have proved to be valuable in uncovering the presence and the impact of hormone-like compounds in the wildlife [34]. Reporter gene assays were largely used to analyse samples such as harbour sediment and wasted waters [35, 36], but only few studies were conducted to assess the hormonal activity of biological tissues [37-39].

\section{Material and Methods}

2.1. Equipment, Chemicals, and Reagents. The following equipment and materials have been used in this study: carbon dioxide (Air Liquide, Liège, Belgium); helium (Air Products, Brussels, Belgium); acetonitrile (Biosolve, Valkenswaard, Netherlands); luminometer Orion II (BRS, Drogenbos, Belgium); adenosine triphosphate (ATP), Dulbecco's modified Eagle's medium (DMEM), DMEM without red phenol, and fetal bovine serum and trypsin (Fisher Bioblock Scientific, Tournai, Belgium); Focus gas chromatograph and Polaris Q mass spectrometer (Interscience, Louvain-laNeuve, Belgium); charcoal, dextran, $o, p^{\prime}$-DDD, $p, p^{\prime}$-DDD, $p, p^{\prime}$-DDE, $o, p^{\prime}$-DDT, $p, p^{\prime}$-DDT, $17 \beta$-estradiol, HCB, $\alpha-\mathrm{HCH}$, $\beta-\mathrm{HCH}, \gamma-\mathrm{HCH}, \delta-\mathrm{HCH}$, nonane, PCB $80{ }^{13} \mathrm{C}, \mathrm{PCB} 138$ $\left(2,2^{\prime}, 3,4,4^{\prime}, 5^{\prime}\right.$-hexachlorobiphenyl), PCB $153\left(2,2^{\prime}, 4,4^{\prime}, 5,5^{\prime}\right.$ hexachlorobiphenyl), and PCB $180\left(2,2^{\prime}, 3,4,4^{\prime}, 5,5^{\prime}\right.$-heptachlorobiphenyl) (Sigma-Aldrich, Bornem, Belgium); Dluciferin (potassium salt) (Synchem OHG, Kassel, Germany); HT8 column (VWR, Leuven, Belgium).

2.2. Stable Reporter Cell Lines and Culture. To obtain an estrogen-responsive cell line, MCF-7 human mammary tumour cells were stably transformed with a reporter vector containing the firefly luciferase gene under control of the vitellogenin promoter $[24,40]$. These cells were grown in $75 \mathrm{~cm}^{2}$ culture flasks in DMEM, supplemented by $10 \%$ heatinactivated foetal bovine serum (FBS), at $37^{\circ} \mathrm{C}$ under $5 \% \mathrm{CO}_{2}$.

2.3. Samples. Blubber samples were obtained from 12 juvenile harbour porpoises ( 8 males and 4 females) stranded on the Belgian and French North Sea coasts between 2000 and 2003. These animals were necropsied by the Laboratory for Oceanology of the University of Liège according to standard procedures detailed elsewhere [3]. Blubber samples were identified by an alphanumeric code and kept apart at $-20^{\circ} \mathrm{C}$ until analysis.

2.4. Extraction Procedure. To separate POPs from blubber samples, we applied a solid-liquid extraction to extract fat with the POPs. This step was followed by an acid silica column chromatography to eliminate the fat. Using this method, we destroyed endogenous steroid hormones and their eventual conjugates, which were hydrolysed in presence of inorganic 
acids [41]. The advantage of this method is that natural hormones present in the samples could be eliminated from the extracts and would not interfere in the estrogen-like activity elicited by samples as pointed out by some authors [42].

The extraction was performed as follows. One g of harbour porpoise blubber was homogenized in a test tube containing $2 \mathrm{~mL}$ of hexane using a glass stirring rod. The organic phase was separated and the hexane evaporated under nitrogen until dryness. Then, $0.25 \mathrm{~g}$ or $0.1 \mathrm{~g}$ of the extracted fat was solubilised in two different tubes containing $2 \mathrm{~mL}$ of hexane for the estrogen receptor- (ER-) mediated activity assays and GC-MS analyses, respectively. The fat solubilised in hexane was applied to a glass column, prewashed with hexane, filled (from the bottom to top) with $5 \mathrm{~g}$ of acid silica (40\% $\mathrm{H}_{2} \mathrm{SO}_{4} \mathrm{w} / \mathrm{w}$ ), $1 \mathrm{~g}$ of deactivated alumina, and $1 \mathrm{~g}$ of $\mathrm{Na}_{2} \mathrm{SO}_{4}$. POPs were eluted with a mixture of dichloromethane and hexane $(1: 3)$, the eluent was evaporated to dryness. The residue of the first tube was recovered in $25 \mu \mathrm{L}$ of acetonitrile for the estrogen receptor- (ER-) mediated activity assays, and the residue of the second tube was recovered in $100 \mu \mathrm{L}$ of nonane containing $10 \mu \mathrm{L}$ of an internal standard (PCB 80 ${ }^{13} \mathrm{C} 1.0 \mathrm{ng} / \mu \mathrm{L}$ ) for GC-MS analysis. In order to measure the possible loss of the estrogenic activity due to the extraction and purification procedure, a solution containing 13 POPs (see below) was submitted to the extraction/purification procedure and the extracts were then analysed by reporter gene assay. A procedure blank was performed to measure the background response in the reporter gene assay.

2.5. Cell-Based Assays to Test Estrogen Receptor- (ER-) Mediated Activity. The cell-based assays for estrogen receptor ER-mediated activity were carried out as follows. Ninety $\%$ confluent MCF-7-ERE cells were cultured at least $24 \mathrm{~h}$ in DMEM without phenol red (supplemented by $10 \%$ of FBS previously treated with charcoal-dextran), and they were released from the culture flask using $1.5 \mathrm{~mL}$ of trypsin $(0.5 \mathrm{~g} / \mathrm{L})$. Then, cells were suspended in $10 \mathrm{~mL}$ of fresh culture medium and this suspension was diluted two times. One hundred $\mu \mathrm{L}$ of diluted cells was seeded in 96-well culture plates, which were incubated overnight at $37^{\circ} \mathrm{C}$ under $5 \%$ $\mathrm{CO}_{2}$. Afterwards, cells were incubated with the standards or the extracts of blubber samples to be tested for 24 hours. The final volume in one well was $200 \mu \mathrm{L}$. A $17 \beta$-estradiol (E2) calibration curve was performed on each plate $(7.0 \times$ $10^{-5} \sim 2.0 \times 10^{-1} \mathrm{ng} \mathrm{E} 2 / \mathrm{mL}$ culture medium containing $0.8 \%$ acetonitrile). To study agonistic activity of the standards or the extracts of blubber samples (ability to mimic endogenous hormones), cells were exposed, one at a time, to a selection of 13 individual POPs $\left(o, p^{\prime}-\mathrm{DDD}, p, p^{\prime}-\mathrm{DDD}, p, p^{\prime}-\mathrm{DDE}, o, p^{\prime}\right.$ DDT, $p, p^{\prime}$-DDT, HCB, $\alpha-\mathrm{HCH}, \beta-\mathrm{HCH}, \gamma-\mathrm{HCH}, \delta-\mathrm{HCH}$, PCB 138, PCB 153, and PCB 180) or blubber extracts diluted in acetonitrile. Each POP was tested individually at three different concentrations: 80, 400, and $2000 \mathrm{ng} / \mathrm{mL}$ culture medium. Then, seven mixtures containing the same weight proportion of each POP (to reach final global concentrations of 80,400 , and $2000 \mathrm{ng} / \mathrm{mL}$ culture medium) were tested. The final proportion of acetonitrile in the medium in the agonistic tests was $0.4 \%$. To study the antiestrogenic activity of the
TABLE 1: $m / z$ ratios scanned and corresponding windows of elution times for each target compound.

\begin{tabular}{|c|c|c|}
\hline$m / z$ ratios & $\begin{array}{l}\text { Elution } \\
\text { time (min) }\end{array}$ & Target compound \\
\hline $181 / 183$ & $11.5-16.0$ & $\alpha-\mathrm{HCH}$ \\
\hline $284 / 285$ & $11.5-16.0$ & $\mathrm{HCB}$ \\
\hline $181 / 183$ & $16.0-28.0$ & $\gamma-\mathrm{HCH}, \beta-\mathrm{HCH}$, and $\delta-\mathrm{HCH}$ \\
\hline $302 / 304$ & $28.0-30.0$ & PCB $80{ }^{13} \mathrm{C}$ \\
\hline $235 / 237$ & $30.0-31.4$ & $o, p^{\prime}-\mathrm{DDD}$ \\
\hline $316 / 318$ & $30.0-31.4$ & $p, p^{\prime}-\mathrm{DDE}$ \\
\hline $235 / 237$ & $31.4-33.3$ & $o, p^{\prime}-\mathrm{DDT}, p, p^{\prime}-\mathrm{DDD}$, and $p, p^{\prime}-\mathrm{DDT}$ \\
\hline $360 / 362$ & $31.4-33.3$ & PCB 153 and PCB 138 \\
\hline $394 / 396$ & $33.3-36.0$ & PCB 180 \\
\hline
\end{tabular}

tested standards or the extracts of blubber samples (ability to inhibit the binding of a hormone to its receptor), the cells were exposed to increasing concentrations $(80,400$, or $2000 \mathrm{ng} / \mathrm{mL}$ culture medium) of a selection of POPs, alone or within mixtures, or to blubber extracts diluted in acetonitrile in the presence of the reference ligand (E2) at a concentration near its $\mathrm{EC}_{50}\left(\approx 5.0 \times 10^{-3} \mathrm{ng} \mathrm{E} 2 / \mathrm{mL}\right.$ culture medium $)$. The final proportion of acetonitrile in the medium in this case was $0.8 \%$. After incubation, the cell viability was checked under a microscope. Subsequently, the medium was removed and the cells were lysed with $50 \mu \mathrm{L}$ of lysis solution containing $25 \mathrm{mM}$ of Tris, $2 \mathrm{mM}$ of 1,4-dithiothreitol, $2 \mathrm{mM}$ of $1,2-$ diaminocyclohexanetetraacetic acid, $10 \%$ of glycerol, and $1 \%$ of Triton X-100. After the addition of luciferin and ATP, the luciferase activity was determined using a luminometer and reported as relative light units (RLU). The bend points (beginning and end of the essentially linear region of the sigmoid dose-response curves) were defined as published by Sebaugh and McCray [43]. The minimal relative response was set to $17.6 \%$ to consider an accurate measurement.

2.6. Chemical Analyses by GC-MS. Analyses of extracts were performed using a Focus gas chromatograph coupled to a Polaris Q ion trap mass spectrometer. Helium was used as carrier gas at a flow rate of $1 \mathrm{~mL} / \mathrm{min}$. A volume of $2.0 \mu \mathrm{L}$ was injected. Separation of the target analytes was performed on a HT8 column $(25 \mathrm{~m} \times 0.22 \mathrm{~mm} \times$ film thickness $0.25 \mu \mathrm{m})$. Injector and ion source temperatures were $250^{\circ} \mathrm{C}$ and $220^{\circ} \mathrm{C}$, respectively. The GC conditions were the following: $2 \mathrm{~min}$ at $120^{\circ} \mathrm{C}$, ramped to $169^{\circ} \mathrm{C}\left(30^{\circ} \mathrm{C} / \mathrm{min}\right), 13 \mathrm{~min}$ at $169^{\circ} \mathrm{C}$, ramped to $170^{\circ} \mathrm{C}\left(5^{\circ} \mathrm{C} / \mathrm{min}\right), 9 \mathrm{~min}$ at $170^{\circ} \mathrm{C}$, ramped to $247^{\circ} \mathrm{C}$ $\left(30^{\circ} \mathrm{C} / \mathrm{min}\right), 2 \mathrm{~min}$ at $247^{\circ} \mathrm{C}$, ramped to $320^{\circ} \mathrm{C}\left(20^{\circ} \mathrm{C} / \mathrm{min}\right)$, and $2 \mathrm{~min}$ at $320^{\circ} \mathrm{C}$. The total run time was $36 \mathrm{~min}$. Spectra were acquired in single ion monitoring (SIM) mode. The $\mathrm{m} / \mathrm{z}$ ratios scanned (with corresponding elution times) can be found in Table 1: 181, 183, 284, and 285 (11.5-16.0 min); 181 and 183 (16.0-28.0 $\mathrm{min}$ ); 302 and 304 (28.0-30.0 $\mathrm{min}$ ); 235, $237,316$, and 318 (30.0-31.3 $\mathrm{min}) ; 235,237,360$, and 362 (31.4$33.3 \mathrm{~min}) ; 235,237,360$, and 362 (31.4-33.3 $\mathrm{min}) ; 394$ and 396 (33.3-36.0 $\mathrm{min})$. For each compound, 5 calibration solutions $(20,60,120,240$, and $400 \mathrm{pg} / \mu \mathrm{L})$, including the internal 
standard, were injected in parallel to samples extracts. The limit of detection was $1 \mu \mathrm{g} / \mathrm{kg}$ fat.

2.7. Data Analysis. Cell-based assays for estrogen receptor(ER-) mediated activity data were processed with Slide Write V6 software. Reference curves were fitted using the sigmoid dose-response curve equation: $Y=a_{0} /\left(1+\left(x / a_{1}\right)^{a_{2}}\right)$, where $x$ is the concentration of $\mathrm{E} 2, Y$ is the relative response $\left(\left(\mathrm{RLU}_{\text {sample }}-\mathrm{RLU}_{\text {blank solvent }}\right) /\left(\mathrm{RLU}_{17 \beta \text {-estradiol maximal dose }}-\right.\right.$ $\left.\left.\mathrm{RLU}_{\text {blank solvent }}\right)\right), a_{1}$ is the concentration of half-maximal response $\left(\mathrm{EC}_{50}\right)$, and $a_{2}$ is the slope of the linear part of the curve. This equation was used to convert relative responses obtained for tested compounds or blubber samples extracts into estradiol equivalents (EEQ) expressed in $\mathrm{ng} / \mathrm{mL}$ culture medium, for POPs standards and mixtures, and in $\mu \mathrm{g} / \mathrm{kg}$ fat, for blubber samples. Chemical analyses by GC-MS were processed using Xcalibur software (InterScience).

Student's $t$-tests were performed to determine which compounds and blubber samples produced a response significantly different from the blank in the case of agonistic tests and which compounds and blubber samples produced a response significantly different from the reference ligand (E2 at $5.0 \times 10^{-3} \mathrm{ng} / \mathrm{mL}$ culture medium) in the case of antagonistic tests.

\section{Results}

3.1. Characterization of the MCF-7-ERE Cell Line. After exposing MCF-7-ERE cells to increasing concentrations of E2, sigmoid dose-response curves were obtained with an average coefficient of determination $\left(R^{2}\right)$ of $0.99 \pm 0.0049$ $(n=10)$. The MCF-7-ERE cell line responded specifically to its reference ligand E2 and concentrations as low as $1.1 \times$ $10^{-3} \mathrm{ng} / \mathrm{mL}$ of this hormone resulted in a reproducible signal, suggesting that this cell line is able to detect estrogen-like activity. The half maximal effective concentration $\left(\mathrm{EC}_{50}\right)$ of E2 was $4.4 \times 10^{-3} \pm 1.5 \times 10^{-3} \mathrm{ng} / \mathrm{mL}$ (Figure 1 ).

3.2. Extraction and Purification of Samples. When applying the extraction and purification procedure to a mixture of 13 POPs, we noticed that $76 \pm 3 \%$ of the initial estrogenic activity was recovered. As expected, a solution containing E2 showed no estrogenic activity after being submitted to the extraction/purification procedure, indicating that E2 was undoubtedly degraded by the acidified silica of the column. The procedure blank (negative control) showed a relative response of $7 \%$, below the threshold of $17.6 \%$, needed to evidence an estrogenic activity. This indicates that the extraction/purification method does not induce any estrogenic activity and is thus compatible with the reporter gene assay. Likewise, when E2 was added to the extract obtained from the procedure blank, MCF-7-ERE cells responded positively and in the expected intensity, confirming that the extraction and purification methods do not bring any inhibiting effect to the cells (data not shown).

3.3. Detection of Estrogen Receptor- (ER-) Mediated Activity of POPs in MCF-7-ERE Cells. For each selected compound,

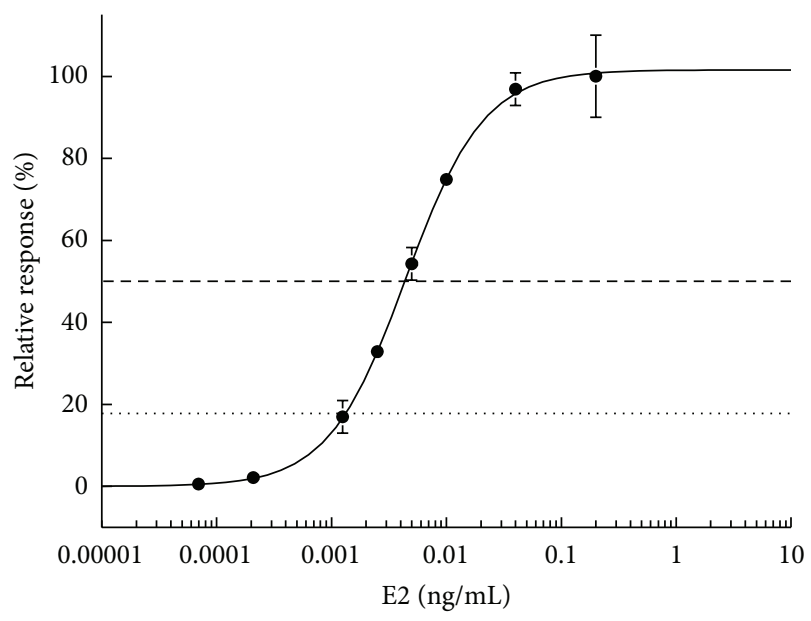

FIgURE 1: Dose-response curve of increasing concentrations of E2 (ng/mL culture medium). Data represent the mean \pm S.D $(n=$ 10). The maximal response observed for E2 was arbitrarily set to $100 \%$. The dotted line represents the minimal relative response to consider an estrogenic activity (17.6\% of response) and the dashed line represents $\mathrm{EC}_{50}$.

the maximum relative response was obtained at the concentration of $2000 \mathrm{ng} / \mathrm{mL}$ culture medium (Table 2), with no apparent cytotoxicity when observing the cells under the microscope. None of the tested PCBs was able to induce a cell response above $17.6 \%$. The five compounds belonging to the group of DDT and its metabolites presented a strong estrogenic activity, especially $o, p^{\prime}$-DDT and $o, p^{\prime}$-DDD, which produced a maximum relative response higher than $60 \%$. Among the hexachloro compounds, $\beta-\mathrm{HCH}$ and $\delta-\mathrm{HCH}$ were the compounds with the strongest estrogenic activity, with responses of 64 and $20 \%$, respectively, at the concentration of $2000 \mathrm{ng} / \mathrm{mL}$ culture medium (Table 2).

In order to detect a possible interaction between the chemicals mentioned before, MCF-7-ERE cells were also exposed to mixtures containing the same weight proportion of each molecule included in the mixture to reach a final concentration of $80 \mathrm{ng} / \mathrm{mL}, 400 \mathrm{ng} / \mathrm{mL}$, or $2000 \mathrm{ng} / \mathrm{mL}$ culture medium for the sum of all compounds. The mixture of the 3 PCBs (mixture \#1) did not activate the estrogen receptor. The most concentrated mixture of DDT and its metabolites (mixture \#2, $2000 \mathrm{ng} / \mathrm{mL}$ ) contains each congener at a concentration of $400 \mathrm{ng} / \mathrm{mL}$, at which only $o, p^{\prime}$-DDT and $o, p^{\prime}$ DDD showed an activity (relative responses of $67 \%$ and $29 \%$ for $o, p^{\prime}$-DDT and $o, p^{\prime}$-DDD, resp.). However, the response observed for this mixture remains below the response of $o, p^{\prime}$ DDT alone. Similar observation can be made for the mixture of $\mathrm{HCH}$ isomers and $\mathrm{HCB}$ (mixture \#3), the response of the mixture (containing each compound at a concentration of $400 \mathrm{ng} / \mathrm{mL}$ ) being lower $(23 \%)$ than the response of the only compound $(\beta-\mathrm{HCH})$ giving a response $(35 \%)$ at the concentration of $400 \mathrm{ng} / \mathrm{mL}$. When mixing the mixtures (binary or ternary mixtures, see the four last lines of Table 2), the response obtained corresponds to the response of the most potent mixture included in the "mixture of mixtures." 
TABLE 2: Estrogen receptor-mediated luciferase expression (measured as light emission) observed in MCF-7-ERE cells exposed during 24 hours to single compounds or mixtures of selected POPs. All mixtures contained the same weight proportion of the constituents to achieve the concentration of $80 \mathrm{ng} / \mathrm{mL}, 400 \mathrm{ng} / \mathrm{mL}$, or $2000 \mathrm{ng} / \mathrm{mL}$ medium $(n=3)$.

\begin{tabular}{|c|c|c|c|c|c|c|}
\hline & \multicolumn{3}{|c|}{ Relative response $(\%)^{\mathrm{a}}$} & \multicolumn{3}{|c|}{$\operatorname{EEQ}(\mathrm{ng} / \mathrm{mL})^{\mathrm{b}}$} \\
\hline & $80 \mathrm{ng} / \mathrm{mL}$ & $400 \mathrm{ng} / \mathrm{mL}$ & $2000 \mathrm{ng} / \mathrm{mL}$ & $80 \mathrm{ng} / \mathrm{mL}$ & $400 \mathrm{ng} / \mathrm{mL}$ & $2000 \mathrm{ng} / \mathrm{mL}$ \\
\hline PCB 138 & $<$ LOQ & $<$ LOQ & $<$ LOQ & $\mathrm{n} / \mathrm{a}$ & $\mathrm{n} / \mathrm{a}$ & $\mathrm{n} / \mathrm{a}$ \\
\hline PCB 153 & $<\mathrm{LOD}$ & $<\mathrm{LOD}$ & $<$ LOQ & $\mathrm{n} / \mathrm{a}$ & $\mathrm{n} / \mathrm{a}$ & $\mathrm{n} / \mathrm{a}$ \\
\hline PCB 180 & $<$ LOD & $<\mathrm{LOD}$ & $<\mathrm{LOD}$ & $\mathrm{n} / \mathrm{a}$ & $\mathrm{n} / \mathrm{a}$ & $\mathrm{n} / \mathrm{a}$ \\
\hline Mixture of PCB congeners (1) & $<$ LOD & $<\mathrm{LOD}$ & $<$ LOQ & $\mathrm{n} / \mathrm{a}$ & $\mathrm{n} / \mathrm{a}$ & $\mathrm{n} / \mathrm{a}$ \\
\hline$o, p^{\prime}-\mathrm{DDT}$ & $28 \pm 0$ & $67 \pm 3$ & $72 \pm 7$ & $2.1 \pm 0.0 \times 10^{-3}$ & $7.6 \pm 0.8 \times 10^{-3}$ & $9.4 \pm 2.4 \times 10^{-3}$ \\
\hline$o, p^{\prime}-\mathrm{DDD}$ & $<\mathrm{LOD}$ & $29 \pm 3$ & $66 \pm 3$ & $\mathrm{n} / \mathrm{a}$ & $2.1 \pm 0.2 \times 10^{-3}$ & $7.3 \pm 0.6 \times 10^{-3}$ \\
\hline$p, p^{\prime}-\mathrm{DDT}$ & $<\mathrm{LOD}$ & $<$ LOQ & $36 \pm 2$ & $\mathrm{n} / \mathrm{a}$ & $\mathrm{n} / \mathrm{a}$ & $2.8 \pm 0.2 \times 10^{-3}$ \\
\hline$p, p^{\prime}-\mathrm{DDD}$ & $<\mathrm{LOD}$ & $<$ LOQ & $32 \pm 2$ & $\mathrm{n} / \mathrm{a}$ & $\mathrm{n} / \mathrm{a}$ & $2.4 \pm 0.2 \times 10^{-3}$ \\
\hline$p, p^{\prime}-\mathrm{DDE}$ & $<$ LOD & $<$ LOQ & $21 \pm 1$ & $\mathrm{n} / \mathrm{a}$ & $\mathrm{n} / \mathrm{a}$ & $1.5 \pm 0.0 \times 10^{-3}$ \\
\hline Mixture of DDT and its metabolites (2) & $<\mathrm{LOQ}$ & $26 \pm 1$ & $49 \pm 4$ & $\mathrm{n} / \mathrm{a}$ & $1.9 \pm 0.1 \times 10^{-3}$ & $4.3 \pm 0.5 \times 10^{-3}$ \\
\hline$\beta-\mathrm{HCH}$ & $<\mathrm{LOQ}$ & $35 \pm 2$ & $64 \pm 4$ & $\mathrm{n} / \mathrm{a}$ & $2.7 \pm 0.1 \times 10^{-3}$ & $6.8 \pm 1.0 \times 10^{-3}$ \\
\hline$\delta-\mathrm{HCH}$ & $<$ LOQ & $<$ LOQ & $20 \pm 3$ & $\mathrm{n} / \mathrm{a}$ & $\mathrm{n} / \mathrm{a}$ & $1.4 \pm 0.2 \times 10^{-3}$ \\
\hline$\gamma-\mathrm{HCH}$ & $<\mathrm{LOD}$ & $<$ LOQ & $<$ LOQ & $\mathrm{n} / \mathrm{a}$ & $\mathrm{n} / \mathrm{a}$ & $\mathrm{n} / \mathrm{a}$ \\
\hline$\alpha-\mathrm{HCH}$ & $<\mathrm{LOD}$ & $<$ LOQ & $<$ LOQ & $\mathrm{n} / \mathrm{a}$ & $\mathrm{n} / \mathrm{a}$ & $\mathrm{n} / \mathrm{a}$ \\
\hline $\mathrm{HCB}$ & $<\mathrm{LOD}$ & $<\mathrm{LOD}$ & $<\mathrm{LOD}$ & $\mathrm{n} / \mathrm{a}$ & $\mathrm{n} / \mathrm{a}$ & $\mathrm{n} / \mathrm{a}$ \\
\hline Mixture of $\mathrm{HCH}$ isomers and $\mathrm{HCB}(3)$ & $<$ LOQ & $<$ LOQ & $23 \pm 1$ & $\mathrm{n} / \mathrm{a}$ & $\mathrm{n} / \mathrm{a}$ & $1.7 \pm 0.1 \times 10^{-3}$ \\
\hline Mixture (1) + (2) & $<$ LOQ & $32 \pm 1$ & $52 \pm 2$ & $\mathrm{n} / \mathrm{a}$ & $2.4 \pm 0.1 \times 10^{-3}$ & $4.7 \pm 0.3 \times 10^{-3}$ \\
\hline Mixture (1) + (3) & $<\mathrm{LOQ}$ & $<$ LOQ & $28 \pm 2$ & $\mathrm{n} / \mathrm{a}$ & $\mathrm{n} / \mathrm{a}$ & $2.1 \pm 0.2 \times 10^{-3}$ \\
\hline Mixture (2) + (3) & $<$ LOQ & $20 \pm 7$ & $54 \pm 2$ & $\mathrm{n} / \mathrm{a}$ & $1.5 \pm 0.5 \times 10^{-3}$ & $5.0 \pm 0.3 \times 10^{-3}$ \\
\hline Mixture (1) + (2) + (3) & $<$ LOQ & $27 \pm 1$ & $54 \pm 2$ & $\mathrm{n} / \mathrm{a}$ & $2.0 \pm 0.1 \times 10^{-3}$ & $5.0 \pm 0.3 \times 10^{-3}$ \\
\hline
\end{tabular}

The maximal response observed for E2 was arbitrarily set to $100 \%$ and the responses observed for the chemicals and mixtures are expressed in percentage of the maximal response (relative response).

${ }^{\mathrm{b}}$ Estradiol equivalents were determined by linear extrapolation from calibration curves obtained after exposure to E2 and are expressed in $\mathrm{ng} / \mathrm{mL}$ culture medium.

n/a: not applicable.

None of the selected chemicals showed antiestrogenic activity. Conversely, $o, p^{\prime}$-DDT, $o, p^{\prime}$-DDD, $\beta$-HCH, $\delta$ - $\mathrm{HCH}$, and HCB were able to increase the cellular response when exposed simultaneously to E2 $(p<0.05)$. In this case the predicted theoretical responses for the exposure of MCF-7ERE cells to E2 $\left(5.0 \times 10^{-3} \mathrm{ng} / \mathrm{mL}\right.$ culture medium $)$ simultaneously with $o, p^{\prime}$-DDT, $o, p^{\prime}-\mathrm{DDD}$, or $\beta$-HCH $(2000 \mathrm{ng} / \mathrm{mL}$ culture medium) would reach the plateau of the cell response. However, the measured responses were below 100\% (data not shown).

3.4. Organochlorine Pollutants Determination in North Sea Harbour Porpoise Blubber by Chemical Analyses. Three NDLPCB congeners (PCB 138, PCB 153, and PCB 180), four $\mathrm{HCH}$ isomers $(\alpha-\mathrm{HCH}, \beta-\mathrm{HCH}, \gamma-\mathrm{HCH}$, and $\delta-\mathrm{HCH}), \mathrm{HCB}$, and five components of the DDT group $\left(o, p^{\prime}\right.$-DDD, $p, p^{\prime}-$ DDD, $p, p^{\prime}$-DDE, $o, p^{\prime}$-DDT, and $p, p^{\prime}$-DDT) were quantified in North Sea harbour porpoise blubber samples. After optimisation of GC-MS parameters, the obtained chromatograms presented separated and resolved peaks (Figure 2), which permitted the identification and quantification of the target compounds.

Among the chemicals analysed, the PCBs were the main contaminants in North Sea harbour porpoise blubber, followed by the DDT group and finally by the isomers of $\mathrm{HCH}$ and HCB (Table 3). Within each group, PCB $153\left(6.0 \times 10^{2}\right.$ to
$4.2 \times 10^{4} \mu \mathrm{g} / \mathrm{kg}$ fat $), p, p^{\prime}-\mathrm{DDE}\left(5.1 \times 10^{2}\right.$ to $8.6 \times 10^{3} \mu \mathrm{g} / \mathrm{kg}$ fat $)$, $\gamma$ - $\mathrm{HCH}\left(8.0 \times 10^{1}\right.$ to $4.8 \times 10^{2} \mu \mathrm{g} / \mathrm{kg}$ fat $)$, and HCB $\left(7.6 \times 10^{1}\right.$ to $1.5 \times 10^{3} \mu \mathrm{g} / \mathrm{kg}$ fat) were the compounds found in largest quantities.

3.5. Detection of Estrogen Receptor- (ER-) Mediated Activity of North Sea Harbour Porpoise Blubber Samples. The agonistic and antagonistic activity mediated by the estrogen receptor (ER) elicited by North Sea harbour porpoise blubber samples in MCF-7-ERE cells is reported in Figures 3 and 4, respectively. Two samples showed significant agonistic ERmediated responses: A00/258 and 01/1219 (response significantly different from procedure blank, with $p<0.05$ ). The highest response measured was $24 \%$ of the activity induced by the reference E2 (sample 01/1219), corresponding to $0.045 \mu \mathrm{gEEQ} / \mathrm{kg}$ fat (Figure 3). When exposed simultaneously to E2, eight samples inhibited significantly $(p<$ 0.05 ) the activity of the E2 reference ligand: $01 / 1169,03 / 1238$, A00/1140, A03/1517, 01/847, 01/1219, A00/600, and A00/974. The highest antiestrogenic effect was observed for samples $03 / 1238$, which decreased the cellular response of $16 \%$ (Figure 4).

3.6. Correlation between Xenoestrogens in North Sea Harbour Porpoise Blubber and Estrogen Receptor- (ER-) Mediated Activity. From GC-MS data of sample contamination 

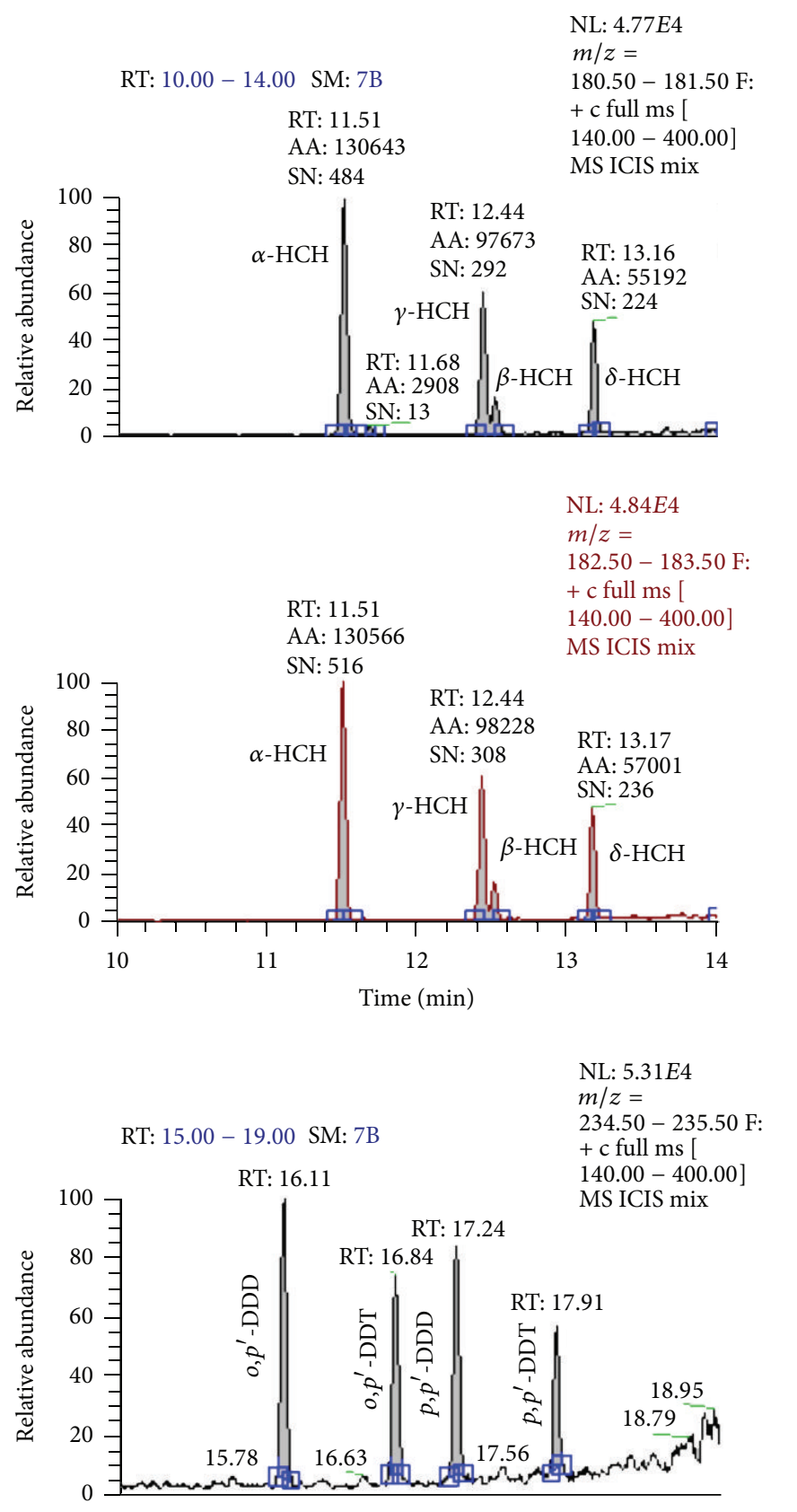

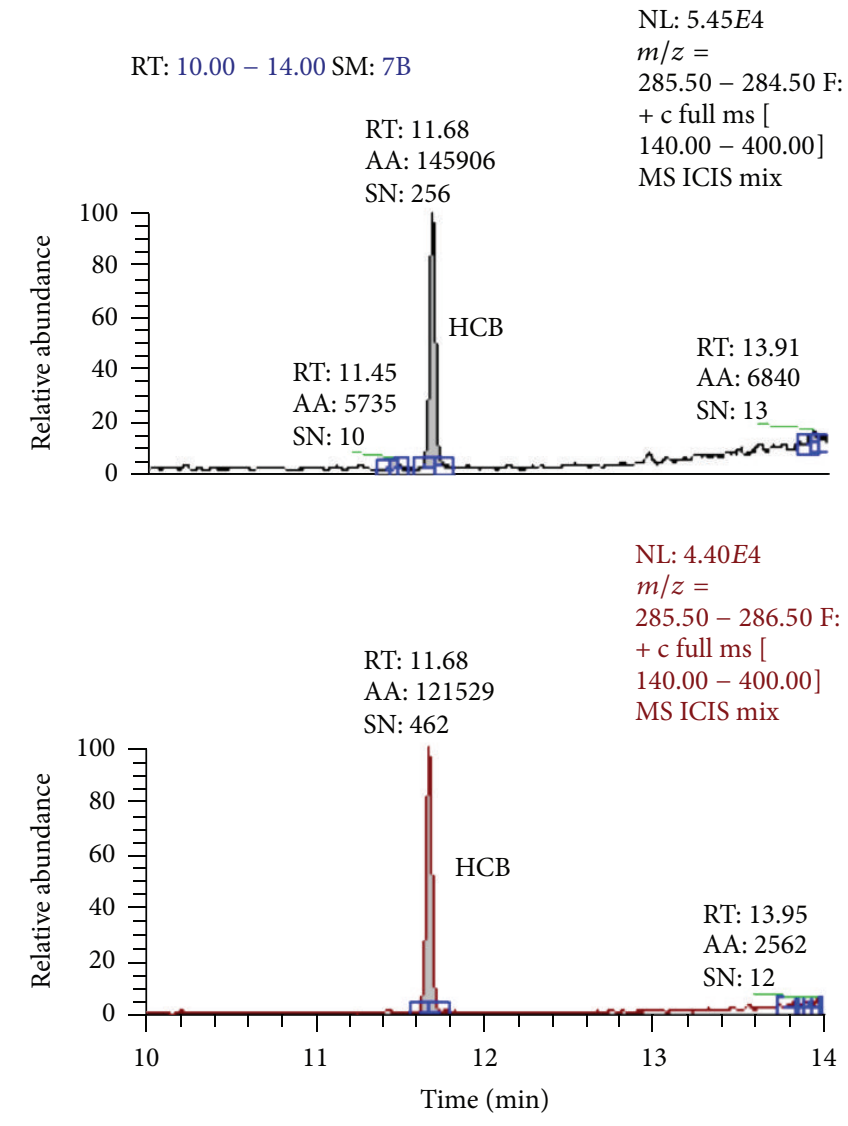

NL: $5.45 E 4$

$285.50-284.50 \mathrm{~F}$ :

$+\mathrm{c}$ full $\mathrm{ms}$ [

$140.00-400.00$ ]

NL: $4.40 E 4$

$\mathrm{m} / z=$

F.

RT: 11.68

$+\mathrm{c}$ full $\mathrm{ms}$

$140.00-400.00]$

RT: $14.00-18.00$

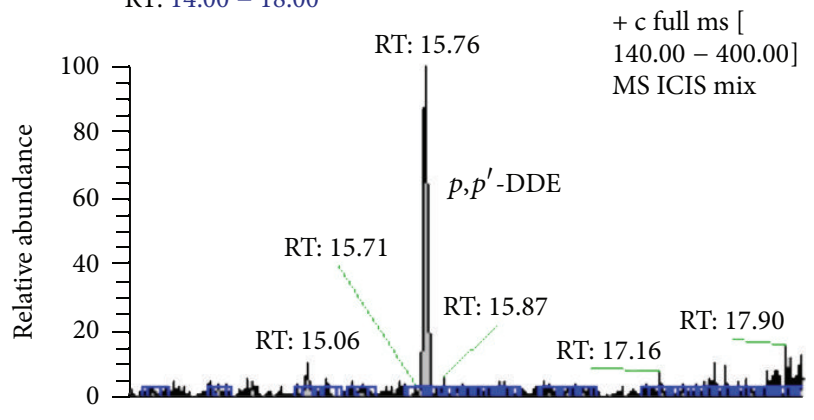

NL: $4.66 E 4$

$\mathrm{m} / z=$

$315.50-316.50 \mathrm{~F}$

$+\mathrm{c}$ full ms [

$140.00-400.00]$

MS ICIS mix
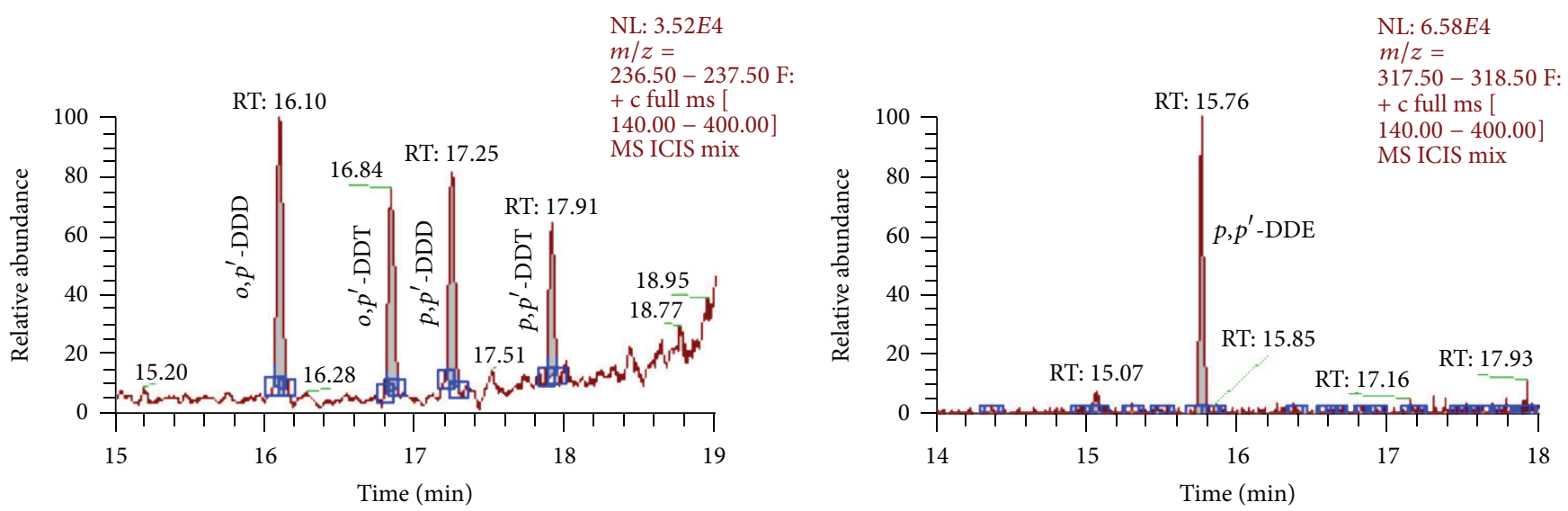

Figure 2: Continued. 


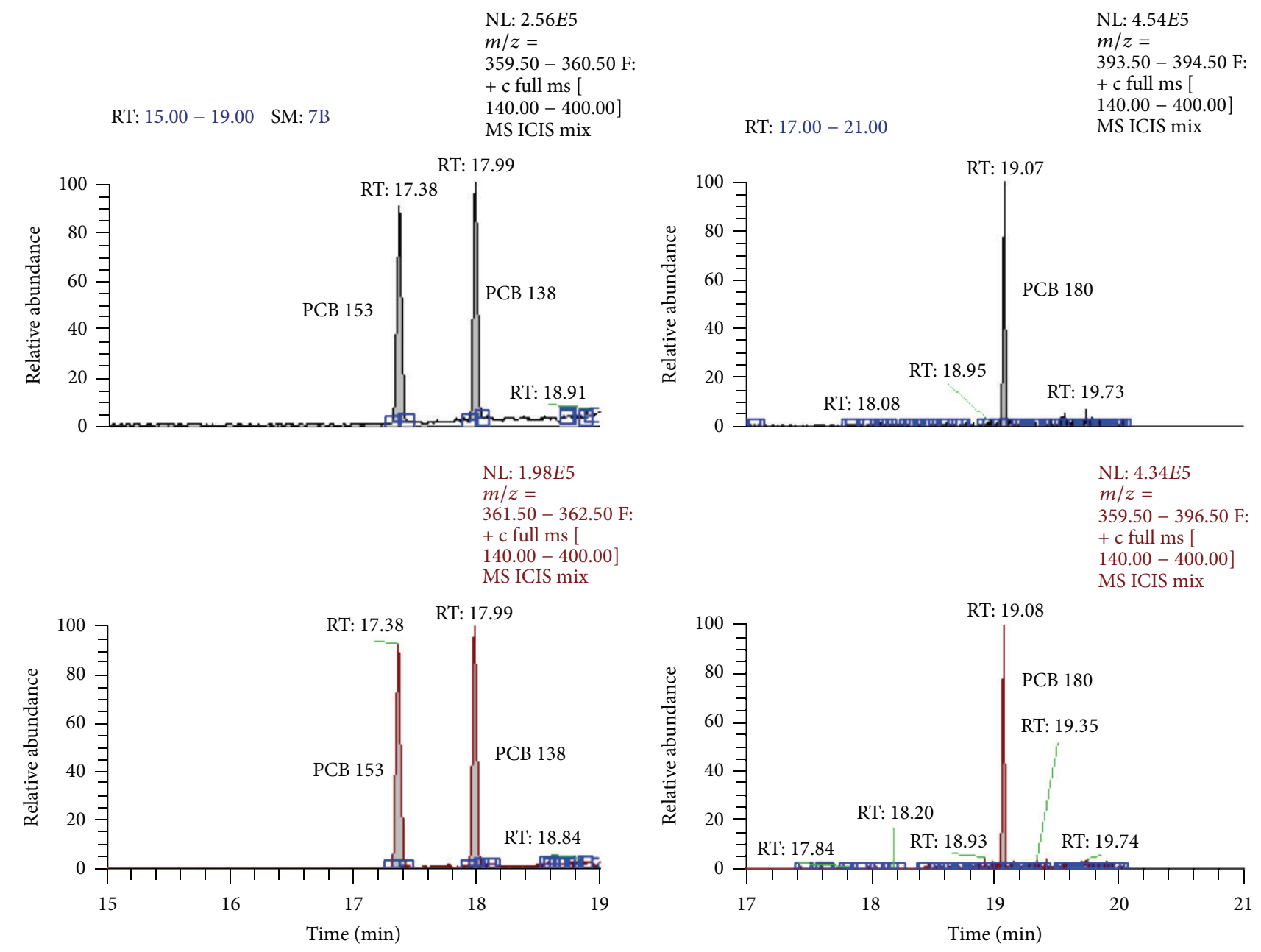

FIGURE 2: Chromatogram of a mixture of 13 standard solutions of target pollutants.

(Table 3), the amount of organochlorine contained in culture medium at the moment of the cell-based assay of blubber samples was calculated (Table 4). When comparing this result to the estrogenic activity of the individual compounds and their mixtures (Table 2), it appeared that none of the samples contained enough of the 13 measured organochlorines to elicit a positive response in the reporter gene assay, either an agonistic or antagonistic, making it not possible to predict the ER-mediated activity of the samples. Indeed, if we look to the levels of $\mathrm{HCH}$ isomers and $\mathrm{HCB}$, they are all below $400 \mathrm{ng} / \mathrm{mL}$ culture medium, which is the smallest concentration tested for individual compounds and at which no response was recorded for these organochlorines in the cell-based assay. From the group of DDT, the most potent substances $\left(o, p^{\prime}\right.$-DDT and $o, p^{\prime}$-DDD) represented only a minor part of the organochlorine contamination, resulting in levels below $80 \mathrm{ng} / \mathrm{mL}$ culture medium in the cell-based assay. However, one sample showed estrogenic activity, seven samples showed antiestrogenic activity, and one sample showed both estrogenic and antiestrogenic activity.

As previously shown, pollutants from the DDT group presented higher estrogenic activities than the other POPs assessed. Moreover, the most potent agonist blubber samples (A00/258 and 01/1219) presented lower $\Sigma_{\mathrm{PCB}} / \Sigma_{\mathrm{DDT}}$ ratios than the sample that inhibited the activity of the natural hormone the most (03/1238). This fact may explain the hormonal activity of samples A00/258 and 01/1219.

The most contaminated sample (A03/1517), containing a total of more than $88 \mathrm{mg}$ organochlorine $/ \mathrm{kg}$ fat, displayed a slight antiestrogenic effect. This can be easily explained by the high contribution of PCBs (more than $81 \mathrm{mg} / \mathrm{kg}$ ), which were not inducing any response in the estrogen-responsive cells.

\section{Discussion}

The study of estrogen receptor- (ER-) mediated activity of POPs in MCF-7-ERE cells showed that several organochlorine pollutants (DDT and metabolites and $\mathrm{HCH}$ isomers) present an estrogenic activity, which was also confirmed by other authors [24, 44-47]. The fact that luciferase gene expression was not induced by PCB 153 and PCB 180 confirms the study of Plíšková et al. [48], where it was observed that higher-chlorinated PCB congeners present low estrogenic activity. It seems that the activity of ER agonism of a PCB 


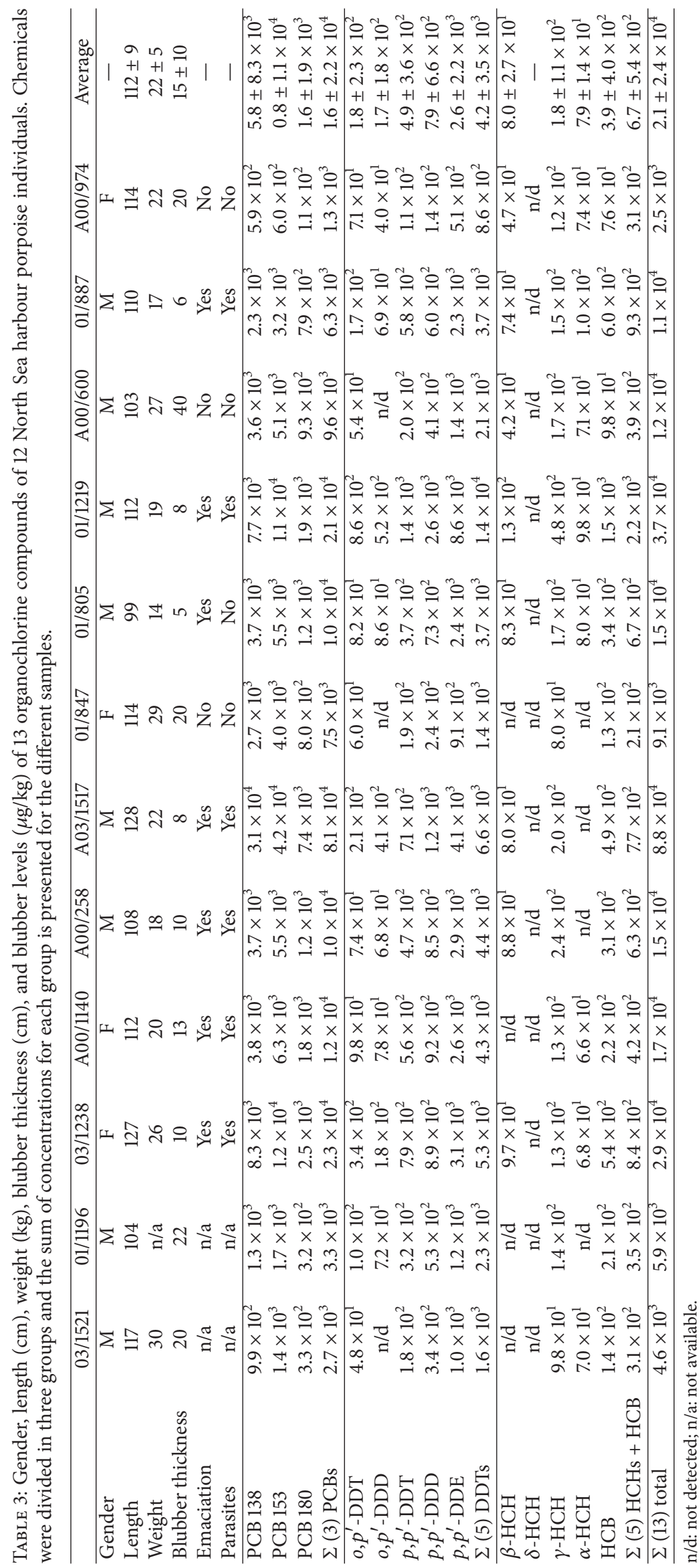




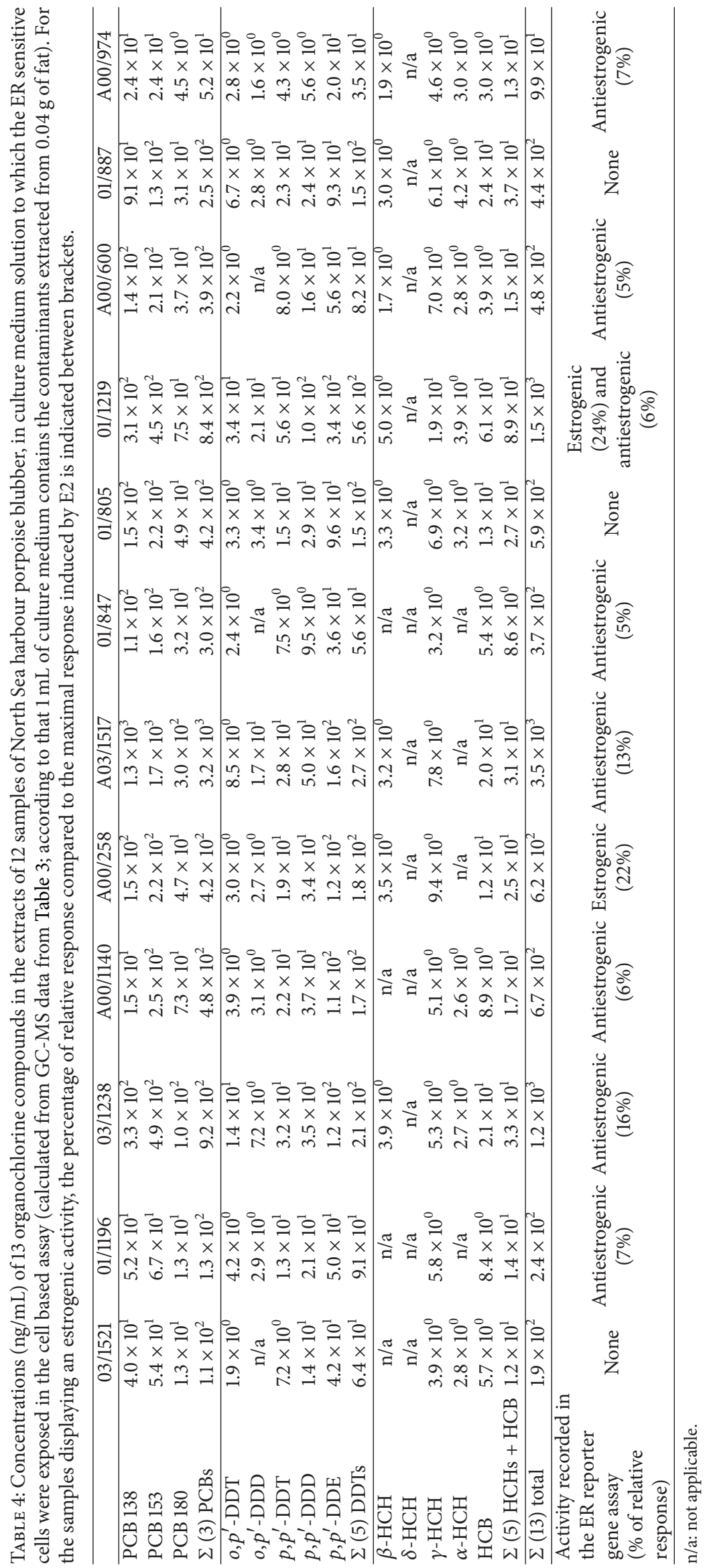



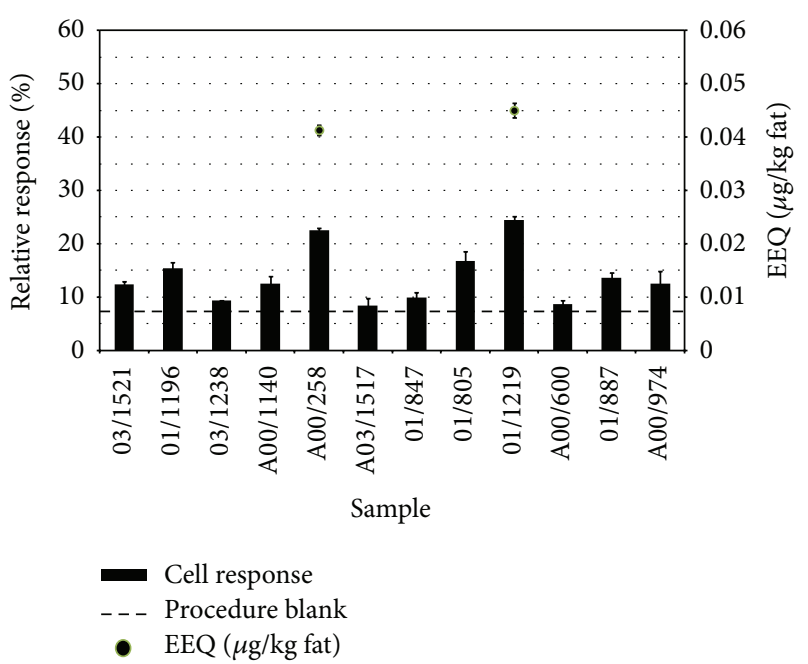

FIGURE 3: Estrogen receptor- (ER-) mediated agonistic activity elicited by 12 North Sea harbour porpoise blubber samples in MCF7-ERE cells. The horizontal dashed line represents the response of the procedure blank. Results are expressed as percent of the maximal response induced by E2 (columns) or as $\mu \mathrm{g} \mathrm{EEQ/kg} \mathrm{fat} \mathrm{(dots),} \mathrm{only}$ for the two samples showing a response significantly different from the procedure blank $(p<0.05)$.

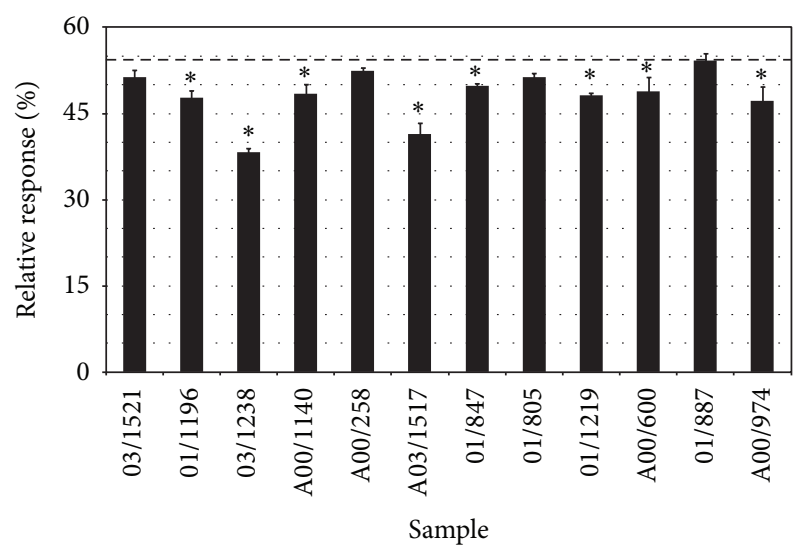

FIGURE 4: Estrogen receptor- (ER-) mediated antagonistic activity elicited by North Sea harbour porpoise blubber samples $(n=12)$ in MCF-7-ERE cells when exposed simultaneously to E2 $(5.0 \times$ $10^{-3} \mathrm{ng} / \mathrm{mL}$ ). The horizontal dashed line represents the response of the cells exposed to $5.0 \times 10^{-3} \mathrm{ng} / \mathrm{mL}$ of E2. Results are expressed as percent of the maximal response induced by E2. Asterisks indicate that the response is significantly different from the response of $5.0 \times$ $10^{-3} \mathrm{ng} / \mathrm{mL}$ of E2 $(p<0.05)$.

is linked to its structure, as larger estrogenic potencies have been reported for low chlorinated compounds [49]. These assays also point out how complex the prediction of the effect of a POP mixture can be. In fact, the approach to investigate endocrine disrupters within mixtures is a new tool that provides clear evidence that POPs have different effects when they are not alone, suggesting that risk assessment should take into consideration the effect of these chemicals within mixture rather than their individual effects [50-54].
Concentrations of organochlorine chemicals found in North Sea harbour porpoise blubber samples are comparable with data formerly published $[5,6,55,56]$. Percentage distribution of PCB congeners was constant between samples and the importance of single congeners was as follows: $153>138$ > 180. Similar profiles were found in various harbour porpoise tissues in previous studies $[10,15,57,58]$. The distribution pattern of PCBs can be explained by differences in structural characteristics within PCB congeners that determine whether a molecule can be easily metabolised by cytochrome P450 enzymes or not.

Metabolites play a dominant role if their persistence exceeds that of the parent product. Even though DDT was banned from utilisation in North America and Western Europe in the 1970s with no new input in the southern North Sea during the last decades [59], the breakdown products of DDT were still detected in the analyzed samples (DDE showing the highest concentrations). In fact, DDT is rapidly metabolised to DDD and slowly metabolised to DDE. Furthermore, DDD has a significantly higher elimination rate than DDE and, subsequently, aquatic animals retain more DDE in their bodies $[60,61]$. Thus, the detected contents of DDD and DDE determined in our samples are possibly due to the breakdown of DDT in the environment.

The high concentration of $\gamma$-HCH in samples is surprising as $\gamma-\mathrm{HCH}$ is relatively rapidly phototransformed to $\alpha-\mathrm{HCH}$ in the environment [62]. This same profile was found in other species of the North Sea [63]. The high concentration of $\gamma$-HCH found in blubber samples may indicate a current utilization of this pesticide in some countries, with a subsequent global scale pollution since both the atmosphere and the ocean are important transport media for $\mathrm{HCH}$ isomers $[64,65]$. Also, $\mathrm{HCH}$ isomers and $\mathrm{HCB}$ were detected in the samples in lower concentration than $\mathrm{PCB}$ congeners and pollutants from the DDT group, possibly because these compounds are easily metabolized and are more water soluble [66].

The large difference of contamination level between samples is probably due to a possible difference in health conditions (e.g., disease or parasitic infection) of the animals, as reported by Pierce et al. [7], maternal transfer, age, and diet. As shown in Table 3, samples from animals that did not present emaciation or parasitic infection figured among the least contaminated. In addition, it was reported that POP concentration in juvenile marine mammals is much higher than in the mothers, since a large portion of the mother's POP burden, transferred to the calf during gestation and lactation, is assimilated into its blubber and other tissues [67], placing juveniles at higher risk [55].

The analyses of blubber samples by cell-based bioassays suggest that POPs measured by GC-MS in this study cannot justify alone the estrogenicity of the extracts and that other endocrine disrupters contaminate the porpoises. Interestingly, the sample showing the highest estrogenic activity and the two samples displaying the highest ER antagonistic activities are among the most contaminated samples. It can be expected that these samples, with a high load of contaminants, also contain other POPs than the 13 organochlorine measured in this study, among which some are agonist or 
antagonist of the estrogen receptor, such as dioxins and furans [68].

\section{Conclusions}

Our study permitted the analysis of harbour porpoise blubber samples both by chemical analysis and cell-based assays, providing consistent data including the level of contamination and the (anti-) estrogenic activity of these samples. Within each group of studied substances, PCB 153, p, $p^{\prime}$-DDE, and $\mathrm{HCB}$ were the compounds found in highest concentrations. Two samples showed estrogenic activity, seven samples showed antiestrogenic activity, and one sample showed both estrogenic and antiestrogenic activity. However, our results suggest that the 13 POPs measured by GC-MS in the samples cannot explain alone the estrogenicity of the extracts and that other EDCs contaminate the porpoises.

High load persistent organic pollutants in porpoise blubber samples indicate that these pollutants can also be found in food from the North Sea, and the hormonal activity measured in some samples confirms the presence of endocrine disrupting chemicals in the marine environment.

\section{Conflict of Interests}

The authors declare that there is no conflict of interests regarding the publication of this paper.

\section{References}

[1] P. S. Hammond, P. Berggren, H. Benke et al., "Abundance of harbour porpoise and other cetaceans in the North Sea and adjacent waters," Journal of Applied Ecology, vol. 39, no. 2, pp. 361-376, 2002.

[2] A. Beineke, U. Siebert, M. McLachlan et al., "Investigations of the potential influence of environmental contaminants on the thymus and spleen of harbor porpoises (Phocoena phocoena)," Environmental Science \& Technology, vol. 39, no. 11, pp. 39333938, 2005.

[3] T. Jauniaux, D. Petitjean, C. Brenez et al., "Post-mortem findings and causes of death of harbour porpoises (Phocoena phocoena) stranded from 1990 to 2000 along the coastlines of Belgium and Northern France," Journal of Comparative Pathology, vol. 126, no. 4, pp. 243-253, 2002.

[4] H. Peltier, H. J. Baagøe, K. C. J. Camphuysen et al., "The stranding anomaly as population indicator: the case of harbour porpoise Phocoena phocoena in north-western europe," PLoS ONE, vol. 8, no. 4, Article ID e62180, 2013.

[5] S. Mössner and K. Ballschmiter, "Marine mammals as global pollution indicators for organochlorines," Chemosphere, vol. 34, no. 5-7, pp. 1285-1296, 1997.

[6] R. J. Law, P. Bersuder, J. Barry, R. Deaville, R. J. Reid, and P. D. Jepson, "Chlorobiphenyls in the blubber of harbour porpoises (Phocoena phocoena) from the UK: levels and trends 1991-2005," Marine Pollution Bulletin, vol. 60, no. 3, pp. 470-473, 2010.

[7] G. J. Pierce, M. B. Santos, S. Murphy et al., "Bioaccumulation of persistent organic pollutants in female common dolphins (Delphinus delphis) and harbour porpoises (Phocoena phocoena) from western European seas: geographical trends, causal factors and effects on reproduction and mortality," Environmental Pollution, vol. 153, no. 2, pp. 401-415, 2008.
[8] S. Tanabe, "Contamination and toxic effects of persistent endocrine disrupters in marine mammals and birds," Marine Pollution Bulletin, vol. 45, no. 1-12, pp. 69-77, 2002.

[9] S. Tanabe, J.-K. Sung, D.-Y. Choi et al., "Persistent organochlorine residues in northern fur seal from the Pacific coast of Japan since 1971," Environmental Pollution, vol. 85, no. 3, pp. 305-314, 1994.

[10] R. Bruhn, N. Kannan, G. Petrick, D. E. Schulz-Bull, and J. C. Duinker, "CB pattern in the harbour porpoise: bioaccumulation, metabolism and evidence for cytochrome p450 IIB activity," Chemosphere, vol. 31, no. 7, pp. 3721-3732, 1995.

[11] J. P. Boon, J. van der Meer, C. R. Allchin et al., "Concentrationdependent changes of PCB patterns in fish-eating mammals: structural evidence for induction of cytochrome P450," Archives of Environmental Contamination and Toxicology, vol. 33, no. 3, pp. 298-311, 1997.

[12] C. D’Amato, J. P. M. Torres, and O. Malm, "DDT (Dichlorodiphenyltrichloroethane): toxicity and environmental contamnation-a review," Química Nova, vol. 25, no. 6A, pp. 995-1002, 2002.

[13] J. A. Alegría-Torres, F. Díaz-Barriga, A. J. Gandolfi, and I. N. Pérez-Maldonado, "Mechanisms of $p, p$ '-DDE-induced apoptosis in human peripheral blood mononuclear cells," Toxicology In Vitro, vol. 23, no. 6, pp. 1000-1006, 2009.

[14] P. C. Abhilash and N. Singh, "Distribution of hexachlorocyclohexane isomers in soil samples from a small scale industrial area of Lucknow, North India, associated with lindane production," Chemosphere, vol. 73, no. 6, pp. 1011-1015, 2008.

[15] A. Covaci, K. Van De Vijver, W. DeCoen et al., "Determination of organohalogenated contaminants in liver of harbour porpoises (Phocoena phocoena) stranded on the Belgian North Sea coast," Marine Pollution Bulletin, vol. 44, no. 10, pp. 1157-1165, 2002.

[16] S. H. Safe, "Endocrine disruptors and human health-is there a problem? An update," Environmental Health Perspectives, vol. 108, no. 6, pp. 487-493, 2000.

[17] M. Muñoz-de-Toro, H. R. Beldoménico, S. R. García et al., "Organochlorine levels in adipose tissue of women from a littoral region of Argentina," Environmental Research, vol. 102, no. 1, pp. 107-112, 2006.

[18] C. Porte, G. Janer, L. C. Lorusso et al., "Endocrine disruptors in marine organisms: approaches and perspectives," Comparative Biochemistry and Physiology Part C: Toxicology \& Pharmacology, vol. 143, no. 3, pp. 303-315, 2006.

[19] D. M. Bila and M. Dezotti, "Endocrine disrupters in the environment: part 1-effects and consequences," Química Nova, vol. 30, no. 3, pp. 651-666, 2007.

[20] P. S. Ross, C. M. Couillard, M. G. Ikonomou et al., "Large and growing environmental reservoirs of Deca-BDE present an emerging health risk for fish and marine mammals," Marine Pollution Bulletin, vol. 58, no. 1, pp. 7-10, 2009.

[21] L. Gustavson, T. M. Ciesielski, J. Bytingsvik et al., "Hydroxylated polychlorinated biphenyls decrease circulating steroids in female polar bears (Ursus maritimus)," Environmental Research, vol. 138, pp. 191-201, 2015.

[22] C. Sonne, R. J. Letcher, T. Ø. Bechshøft et al., “Two decades of biomonitoring polar bear health in Greenland: a review," Acta Veterinaria Scandinavica, vol. 54, supplement 1, p. S15, 2012.

[23] A. G. Smith and S. D. Gangolli, "Organochlorine chemicals in seafood: occurrence and health concerns," Food and Chemical Toxicology, vol. 40, no. 6, pp. 767-779, 2002. 
[24] P. Willemsen, M.-L. Scippo, G. Kausel et al., "Use of reporter cell lines for detection of endocrine-disrupter activity," Analytical and Bioanalytical Chemistry, vol. 378, no. 3, pp. 655-663, 2004.

[25] F. Maranghi, M. Rescia, C. Macrì et al., "Lindane may modulate the female reproductive development through the interaction with ER- $\beta$ : an in vivo-in vitro approach," Chemico-Biological Interactions, vol. 169, no. 1, pp. 1-14, 2007.

[26] P. D. Jepson, P. M. Bennett, R. Deaville, C. R. Allchin, J. R. Baker, and R. J. Law, "Relationships between polychlorinated biphenyls and health status in harbor porpoises (Phocoena phocoena) stranded in the United Kingdom," Environmental Toxicology and Chemistry, vol. 24, no. 1, pp. 238-248, 2005.

[27] A. J. Hall, K. Hugunin, R. Deaville, R. J. Law, C. R. Allchin, and P. D. Jepson, "The risk of infection from polychlorinated biphenyl exposure in the harbor porpoise (Phocoena phocoena): a casecontrol approach," Environmental Health Perspectives, vol. 114, no. 5, pp. 704-711, 2006.

[28] K. Das, A. Vossen, K. Tolley et al., "Interfollicular fibrosis in the thyroid of the harbour porpoise: an endocrine disruption?" Archives of Environmental Contamination and Toxicology, vol. 51, no. 4, pp. 720-729, 2006.

[29] S. Garritano, B. Pinto, M. Calderisi, T. Cirillo, R. AmodioCocchieri, and D. Reali, "Estrogen-like activity of seafood related to environmental chemical contaminants," Environmental Health: A Global Access Science Source, vol. 5, article 9, 2006.

[30] M. Guéguen, J.-C. Amiard, N. Arnich et al., "Shellfish and residual chemical contaminants: hazards, monitoring, and health risk assessment along French coasts," Reviews of Environmental Contamination and Toxicology, vol. 213, pp. 55-111, 2011.

[31] M.-L. Scippo and G. Maghuin-Rogister, "Endocrine disruptors in food: potential impact on human health," Annales de Medecine Veterinaire, vol. 151, no. 1, pp. 44-54, 2007.

[32] S. Nadzialek, C. Vanparys, E. Van der Heiden et al., "Understanding the gap between the estrogenicity of an effluent and its real impact into the wild," Science of the Total Environment, vol. 408, no. 4, pp. 812-821, 2010.

[33] P. Willemsen, M.-L. Scippo, G. Maghuin-Rogister, J. A. Martial, and M. Muller, "Use of specific bioluminescent cell lines for the detection of steroid hormone (ant)agonists in meat producing animals," Analytica Chimica Acta, vol. 473, no. 1-2, pp. 119-126, 2002.

[34] G. Streck, "Chemical and biological analysis of estrogenic, progestagenic and androgenic steroids in the environment," Trends in Analytical Chemistry, vol. 28, no. 6, pp. 635-652, 2009.

[35] C. J. Houtman, P. Booij, E. Jover et al., "Estrogenic and dioxin-like compounds in sediment from Zierikzee harbour identified with CALUX assay-directed fractionation combined with one and two dimensional gas chromatography analyses," Chemosphere, vol. 65, no. 11, pp. 2244-2252, 2006.

[36] K. Cai, C. T. Elliott, D. H. Phillips, M.-L. Scippo, M. Muller, and L. Connolly, "Treatment of estrogens and androgens in dairy wastewater by a constructed wetland system," Water Research, vol. 46, no. 7, pp. 2333-2343, 2012.

[37] C. J. Houtman, A. M. Van Oostveen, A. Brouwer, M. H. Lamoree, and J. Legler, "Identification of estrogenic compounds in fish bile using bioassay-directed fractionation," Environmental Science \& Technology, vol. 38, no. 23, pp. 6415-6423, 2004.

[38] E. Simon, M. H. Lamoree, T. Hamers et al., "Testing endocrine disruption in biota samples: a method to remove interfering lipids and natural hormones," Environmental Science and Technology, vol. 44, no. 21, pp. 8322-8329, 2010.
[39] G. Suzuki, N. M. Tue, S. van der Linden et al., "Identification of major dioxin-like compounds and androgen receptor antagonist in acid-treated tissue extracts of high trophic-level animals," Environmental Science \& Technology, vol. 45, no. 23, pp. 1020310211, 2011.

[40] P. Willemsen, M.-L. Scippo, G. Maghuin-Rogister, J. A. Martial, and M. Muller, "Enhancement of steroid receptor-mediated transcription for the development of highly responsive bioassays," Analytical and Bioanalytical Chemistry, vol. 382, no. 4, pp. 894-905, 2005.

[41] M.-F. Jayle and O. Crépy, "Hydrolyse, extraction et purification des stéroïdes," in Analyses des Stéroïdes Hormonaux: Tome I, M.F. Jayle, Ed., pp. 61-113, Masson et Cie Editeurs, Paris, France, 1961.

[42] A. Rivas, N. Olea, and F. Olea-Serrano, "Human exposure to endocrine-disrupting chemicals: assessing the total estrogenic xenobiotic burden," TrAC: Trends in Analytical Chemistry, vol. 16, no. 10, pp. 613-619, 1997.

[43] J. L. Sebaugh and P. D. McCray, "Defining the linear portion of a sigmoid-shaped curve: bend points," Pharmaceutical Statistics, vol. 2, no. 3, pp. 167-174, 2003.

[44] J. Payne, C. Jones, S. Lakhani, and A. Kortenkamp, “Improving the reproducibility of the MCF-7 cell proliferation assay for the detection of xenoestrogens," Science of the Total Environment, vol. 248, no. 1, pp. 51-62, 2000.

[45] M. Hatakeyama, D. M. Tessier, D. Y. Dunlap, E. Zou, and F. Matsumura, "Estrogenic action of $\beta-\mathrm{HCH}$ through activation of c-Neu in MCF-7 breast carcinoma cells," Environmental Toxicology and Pharmacology, vol. 11, no. 1, pp. 27-38, 2002.

[46] M. Hatakeyama, E. Zou, and F. Matsumura, "Comparison of the characteristic of estrogenic action patterns of $\beta-\mathrm{HCH}$ and heregulin $\beta 1$ in MCF-7 human breast cancer cells," Journal of Biochemical and Molecular Toxicology, vol. 16, no. 5, pp. 209219, 2002.

[47] L. Marabini, E. Chiesara, and S. Radice, "Possible estrogenic effects of some highly bioaccumulated polychlorinated biphenyls (PCB 101, 118,138,153) alone and in mixture in MCF7 breast cancer cells," Toxicology Letters, vol. 172, pp. S49-S50, 2007.

[48] M. Plíšková, J. Vondráček, R. F. Canton et al., "Impact of polychlorinated biphenyls contamination on estrogenic activity in human male serum," Environmental Health Perspectives, vol. 113, no. 10, pp. 1277-1284, 2005.

[49] T. Hamers, J. H. Kamstra, P. H. Cenijn et al., "In vitro toxicity profiling of ultrapure non-dioxin-like polychlorinated biphenyl congeners and their relative toxic contribution to PCB mixtures in humans," Toxicological Sciences, vol. 121, no. 1, pp. 88-100, 2011.

[50] J. Payne, N. Rajapakse, M. Wilkins, and A. Kortenkamp, "Prediction and assessment of the effects of mixtures of four xenoestrogens," Environmental Health Perspectives, vol. 108, no. 10, pp. 983-987, 2000.

[51] G. P. Daston, J. C. Cook, and R. J. Kavlock, "Uncertainties for endocrine disrupters: our view on progress," Toxicological Sciences, vol. 74, no. 2, pp. 245-252, 2003.

[52] H. Tinwell and J. Ashby, "Sensitivity of the immature rat uterotrophic assay to mixtures of estrogens," Environmental Health Perspectives, vol. 112, no. 5, pp. 575-582, 2004.

[53] J. A. van Meeuwen, M. van den Berg, J. T. Sanderson, A. Verhoef, and A. H. Piersma, "Estrogenic effects of mixtures of phytoand synthetic chemicals on uterine growth of prepubertal rats," Toxicology Letters, vol. 170, no. 2, pp. 165-176, 2007. 
[54] H. Habibi, K. Jeffries, E. Nelson, and L. Jackson, "Risk assessment for endocrine disrupting chemical mixtures," Comparative Biochemistry and Physiology Part C: Toxicology \& Pharmacology, vol. 148, no. 4, p. 455, 2008.

[55] L. Weijs, C. van Elk, K. Das, R. Blust, and A. Covaci, "Persistent organic pollutants and methoxylated PBDEs in harbour porpoises from the North Sea from 1990 until 2008: Young wildlife at risk?" Science of the Total Environment, vol. 409, no. 1, pp. 228-237, 2010.

[56] R. J. Law, T. Bolam, D. James et al., "Butyltin compounds in liver of harbour porpoises (Phocoena phocoena) from the UK prior to and following the ban on the use of tributyltin in antifouling paints (1992-2005 \& 2009)," Marine Pollution Bulletin, vol. 64, no. 11, pp. 2576-2580, 2012.

[57] L. Weijs, K. Das, U. Siebert et al., "Concentrations of chlorinated and brominated contaminants and their metabolites in serum of harbour seals and harbour porpoises," Environment International, vol. 35, no. 6, pp. 842-850, 2009.

[58] L. Weijs, A. C. Dirtu, K. Das et al., "Inter-species differences for polychlorinated biphenyls and polybrominated diphenyl ethers in marine top predators from the Southern North Sea. Part 1. Accumulation patterns in harbour seals and harbour porpoises," Environmental Pollution, vol. 157, no. 2, pp. 437-444, 2009.

[59] C. Mahfouz, F. Henry, T. Jauniaux, G. Khalaf, and R. Amara, "Organochlorines in harbour porpoises (Phocoena phocoena) stranded along the southern North Sea between 2010 and 2013," nvironmental Science: Processes \& Impacts, vol. 16, no. 12, pp. 2774-2781, 2014.

[60] R. W. M. Kwong, P. K. N. Yu, P. K. S. Lam, and W.-X. Wang, "Uptake, elimination, and biotransformation of aqueous and dietary DDT in marine fish," Environmental Toxicology and Chemistry, vol. 27, no. 10, pp. 2053-2063, 2008.

[61] R. W. M. Kwong, P. K. N. Yu, P. K. S. Lam, and W.-X. Wang, "Biokinetics and biotransformation of DDTs in the marine green mussels Perna viridis," Aquatic Toxicology, vol. 93, no. 4, pp. 196-204, 2009.

[62] H. J. Benezet and F. Matsumura, "Isomerization of $\gamma$-BHC to $\alpha-$ BHC in the environment," Nature, vol. 243 , no. 5407 , pp. 480 481, 1973.

[63] S. Voorspoels, A. Covaci, J. Maervoet, I. De Meester, and P. Schepens, "Levels and profiles of PCBs and OCPs in marine benthic species from the Belgian North Sea and the Western Scheldt Estuary," Marine Pollution Bulletin, vol. 49, no. 5-6, pp. 393-404, 2004.

[64] L. A. Barrie, D. Gregor, B. Hargrave et al., "Arctic contaminants: sources, occurrence and pathways," Science of the Total Environment, vol. 122, no. 1-2, pp. 1-74, 1992.

[65] N. Saadati, M. P. Abdullah, Z. Zakaria, M. Rezayi, and N. Hosseinizare, "Distribution and fate of $\mathrm{HCH}$ isomers and DDT metabolites in a tropical environment-case study Cameron Highlands-Malaysia," Chemistry Central Journal, vol. 6, no. 1, article 130, 2012.

[66] L. Kleivane, J. U. Skaare, A. Bjørge, E. de Ruiter, and P. J. $\mathrm{H}$. Reijnders, "Organochlorine pesticide residue and PCBs in harbour porpoise (Phocoena phocoena) incidentally caught in Scandinavian waters," Environmental Pollution, vol. 89, no. 2, pp. 137-146, 1995.

[67] M. M. Krahn, M. B. Hanson, G. S. Schorr et al., "Effects of age, sex and reproductive status on persistent organic pollutant concentrations in 'Southern Resident' killer whales,' Marine Pollution Bulletin, vol. 58, pp. 1522-1529, 2009.
[68] J. M. Navas and H. Segner, "Antiestrogenic activity of anthropogenic and natural chemicals," Environmental Science and Pollution Research International, vol. 5, no. 2, pp. 75-82, 1998. 

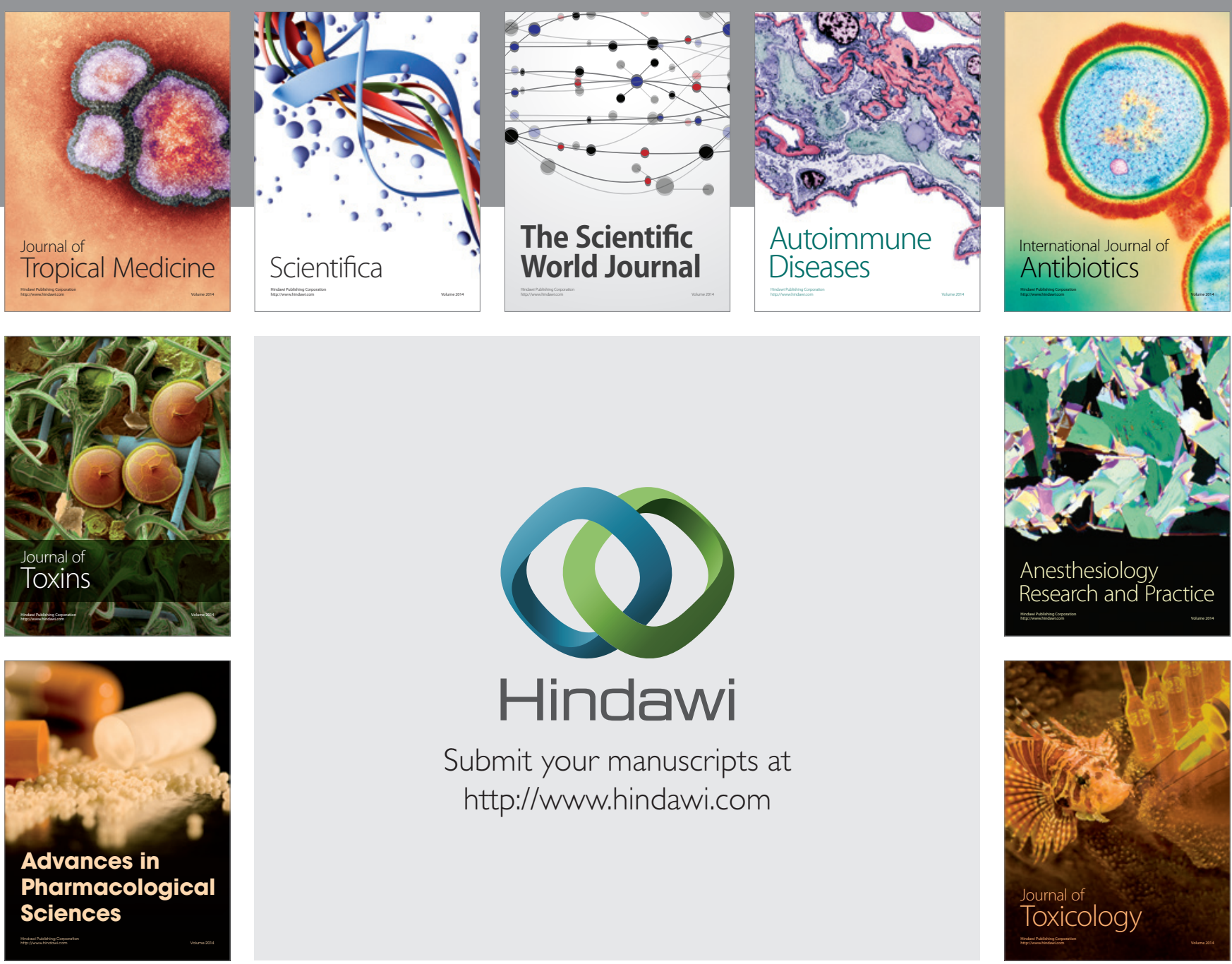

\section{Hindawi}

Submit your manuscripts at

http://www.hindawi.com
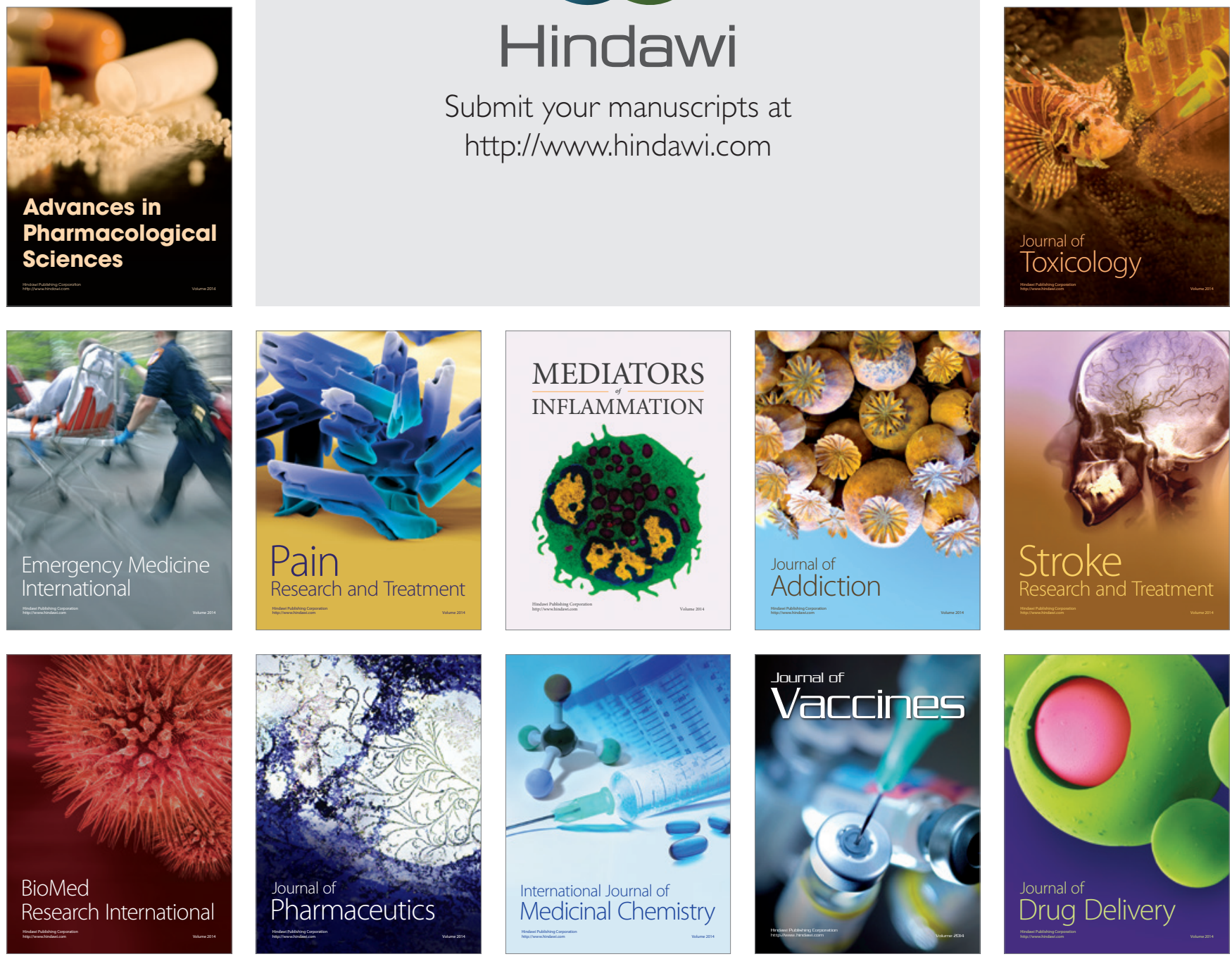